総説

第 22 回日本油化学協会賞・進歩賞

\title{
界面活性剤の溶存状態とその乳化特性に関する研究
}

\author{
塘 久夫 \\ 花王株式会社東京研究所 \\ （于131 東京都墨田区文花 2-1-3）
}

\section{Study on the Solution Behavior and Emulsifying \\ Properties of Surfactants}

\author{
Hisao TSUTSUMI
}

Tokyo Research Laboratories, Kao Corporation

(2-1-3, Bunka, Sumida-ku, Tokyo, †131)

In order to predict the characteristic function and/or novel applications of a surfactant, it is useful to examine the solution behavior of the surfactant into water. Relation between solution behavior and emulsifying properties of surfactants with less solubility into water is discussed in this paper.

Alkylglycerylether (GE) is a surfactant with 2 hydroxyl groups as a hydrophilic portion and it forms liquid crystal with a reversed hexagonal structure in water. On the other hand, GE is such a characteristic emulsifier that can stabilize an W/O emulsion of extremely high water content. This stabilization is due to the formation of liquid crystal in the interfacial layer between oil and water phase.

Thus, emulsifying characteristics of a surfactant is much influenced by the dissolution states in water.

\section{1 はじめに}

まだその性質が明らかにされていない新規な界面活性 物質の，およその性質を知る上で，その物質を水に溶か してみて, どの上うな状態になるかを調べることは大変 役に立つ。その物質に固有の機能や新しい用途を考元る 上でも水中溶存状態を知ることによって多くの手がかり が得られる。

一般に界面活性剂の水への溶存状態は温度及び濃度変 化によもなって様々に変化し，たとえば単分子分散，ミ セル溶液, ヘキサゴナル液晶, ラメラ液晶, 逆へキサゴ ナル液晶, ゲル, 水和溶液あるいは固相の析出した二液 相などの状態となる。この時, ある相から別の相へ変化 する温度 (転移点), あるいは組成 (臨界点) は, それ ぞれの物質が持つ固有の性質（個性）によって決定され る。したがって界面活性物質の水中での溶存状態 (二成 分系の相平衡）を詳しく調べることによって, 親水性 / 疎水性の程度や会合性の強さなど, 基本的な性質を理解 することができる。さらに界面活性物質と水の二成分に 加え油を含む三成分系の相平衡を解析すれば，その物質
の乳化剤あるいは可溶化剤としての特性についても多く の情報を得ることができる。

本稿では界面活性剤の分子構造と水中溶存状態の関 係, また応用特性の一つである乳化性との関係につい て，若干の知見を紹介してみたい。

\section{2 疎水部多鎖構造の界面活性剂の溶存状態 ${ }^{11}$}

界面活性剤の分子構造とその性質との関係については 古くから多くの研究があり, たとえば疎水部の形状とミ セルの会合状態の関係については Hartley の原理が知 られており,また疎水部の炭素鎖長上 $\mathrm{cmc}$ の関係につ いては Traube の規則が知られている。一方, 分子構 造とGross Effects（性能）之の関係についても多く の経験則があり，たとえば疎水部の多鎖化あるいは分岐 化によって乳化力, 分散力は増大し, 逆に起泡力が低下 するなどの現象が知られている。

これに対し界面活性剤の分子構造と水中溶存状態の関 係については比較的多くの研究例はあるものの, 体系 立った研究は少なく, また整理もあまりされていない。 そこで，ここではエチレンオキシド付加型非イオン界面 
活性剂を例にとり, 疎水部の構造変化, 特に多鎖化に よって溶存状態がどのように変化するのか, また乳化特 性によ゙んな影響を及ぼすかについて論じてみたい。

図一1に見城 ${ }^{3)}$ により明らかにされたノニルフェニル ポリ(オキシエチレン) エーテル (以下 NP- $n$ と略記す る。ただし $n$ はエチレンオキシド付加モル数を示す。） と水之の二成分系の相平衡図を示す。眓から明らかなよ うに, $n$ の増加すなわち HLB の増大にともない溶存状 態は親水性へと変化し, たとえば皟り点は上昇し, $\Phi=$ 0.60 (ただし $\Phi$ は界面活性剤の重量分率を示す。) 近傍 で優先的に形成される液晶の形態はラメラ型からへキサ ゴナル型へと变化する。ここで, 単位体積当たり充填さ 得る界面活性剂分子の数は, 分子が平板層状に積み重 なったラメラ型に比べ, 分子が六方円筒状に並んだへキ サゴナル型の方が少ないから,この变化は親水性の増大 によって溶存状態は会合体の会合数が減少する方向に変 化することを意味している。

ところで, 疎水部として分子内に一つの長鎖アルキル 基を有する界面活性剂をモノマー型の界面活性剤と見な せば, 上記のノニルフェニルポリ(オキシエチレン) エーテルはモノマー型界面活性剤である。これに対し,
分子内に二つの長鎖アルキル基を有する界面活性剤は夕゙ イマー型の界面活性剂であり,さらに疎水部が多鎖化し た界面活性剤はオリゴマー型界面活性剂と見なせる。い ま図一2に示したようにオリゴマー型界面活性剤として 疎水部が 3 鎖のポリ (オキシエチレン) 硬化ヒマシ油 (以下 $\mathrm{EC}-n$ 之略記), 疎水部が 4 鎖のポリ（オキシエ チレン) ソルビトールニテトラオレアート（以下 ESTO- $n$ と略記）を取り上げ，その溶存状態をモノ マー型との比較において検討してみよう。

図ー3はエチレンオキシド付加モルの異なる $\mathrm{EC}-n /$ 水二成分系の相平衡図であり, 図 -4 は同じくエチレン オキシド付加モルの異なる一連の ESTO- $n$ /水二成分系 の相平衡図である。いずれもnの増加にともなって溶解 挙動は親水性となり, 曇り点は上昇し，また液晶の形態 もラメラ型よりもへキサゴナル型の方が優先的に形成さ れるようになる。 $n$ の増加によるこの一連の溶存状態の 変化はモノマー型である NP-nの場合と同様の変化で ある。

ここで疎水部の多鎖化による溶存状態の変化を理解す るために, 曇り点がほぼ同じである NP-10, EC-30, 及び ESTO-40 の相平衡図を比較してみよう。この三
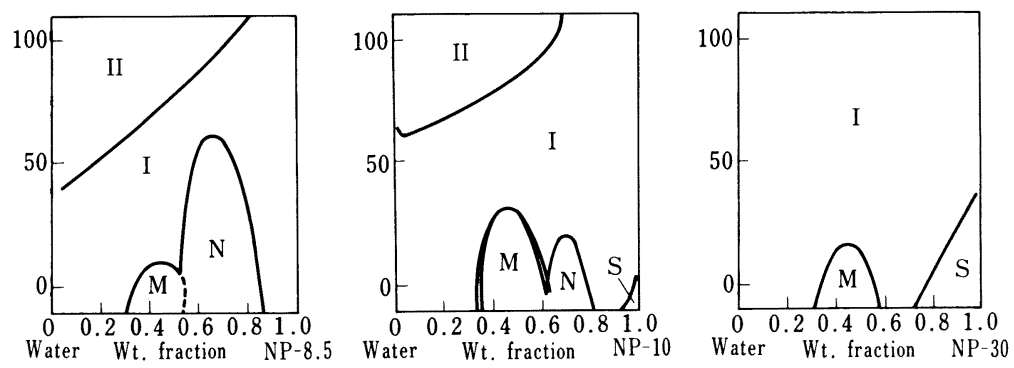

$\mathrm{I}$ : isotropic solution, II : 2 liquids, $\mathrm{M}:$ hexagonal liquid crystal

$\mathrm{N}$ : lamella liquid crystal, $\mathrm{S}:$ solid phase

図-1 NP- $n$ /水二成分系相平衡図

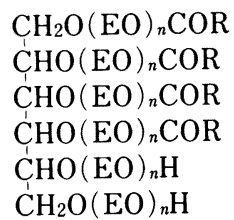

図-2 ポリ(オキシエチレン)ソルビトール = テトラオレアートの分子構造
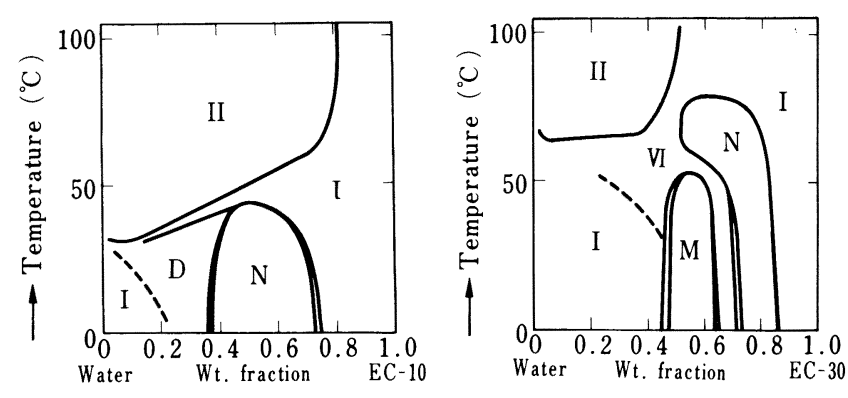

I : Isotropic solution, II : 2 Liquids, D : Dispersion (concentric lamella phase), $\mathrm{N}: \mathrm{L}$ amella liquid crystal $\mathrm{M}:$ Hexagonol liquid crystol

VI : Viscous isotropic phase

図-3 $\mathrm{EC}-n$ /水二成分系相平衡図 

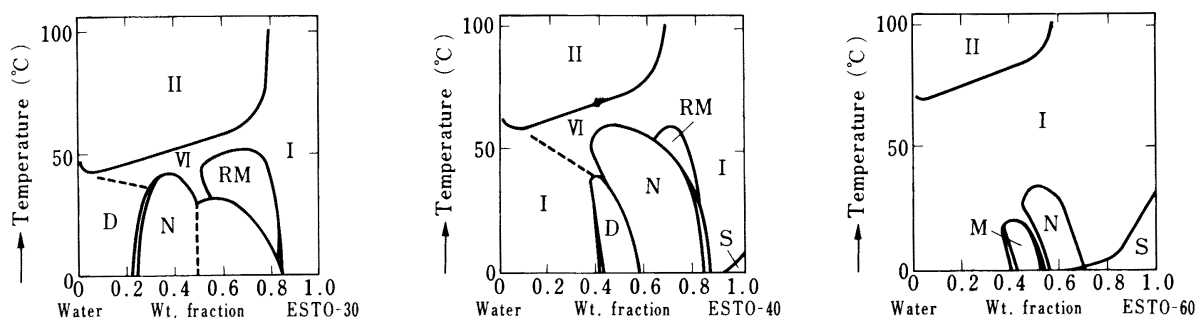

I : Isotropic solution, II : 2 Liquids, D : Dispersion (concentric lamella phase), $\mathrm{N}:$ Lamella liquid crystal

VI : Viscous isotropic phase, RM : reversed hexagonal liquid crystal, $\mathrm{S}:$ Solid phase, $\mathrm{M}:$ hexagonal liquid crystal

図-4 ESTO $-n$ /水二成分系相平衡図

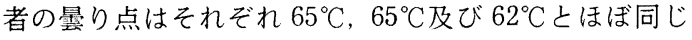
であり，また計算によって求めた HLB 数もそれぞれ 13.3, 11.9, 11.9 とほぼ同じであるにもかかわらず，溶 存状態は大きく異なる。

たとえば $\Phi=0.30$ 近傍での溶存状態は順にミセル溶液 $\rightarrow$ ミセル溶液 $\rightarrow$ concentric lamella 液晶, $\Phi=0.50$ 近 傍ではミセル溶液 $\rightarrow$ ヘキザナル液晶 $\rightarrow$ ラメラ液晶, $\Phi$ $=0.70$ 近傍ではへキサゴナル液晶 $\rightarrow$ ララ夜晶 $\rightarrow$ ララ 液晶, また $\Phi=0.85$ 近傍では逆ミセル溶液（水和溶液）

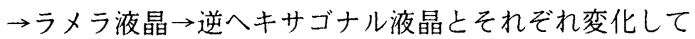
おり，疎水部の多鎖化によって溶存状態は疎水的，すな わち会合数の増える方向へと変化することがわかる。こ れは疎水基の数が増えることによる混合エンタルピーの 增大のためと考えられる。すなわち，H/L バランスを 保ちながらの疎水部の多鎖化は分子量の増大あるいは分 子の大きさの増大を意味するから, 界面活性剂分子と水 との相互作用は減少し，その結果会合数が大きくならな いと水には溶解できなくなる。疎水部多鎖構造の界面活 性剤の溶存状態の特徵はこのように会合数の大きい会合 体を形成して水に溶けること，言い換えれば高次構造を つくりやすいことにあると言える。

\section{3 疎水部多鎖構造の界面活性剂の乳化特性 ${ }^{4}$}

疎水部の多鎖化により乳化剂としての性質はどのよう に変化するのだろうか。この点を前記の ESTO- $n$ を用 いて検討した。図-5 は ESTO- $n$ を乳化剂として用 い，乳化剂濃度を変化させて調製した種々のエマルショ ンの安定性を示している。比較には ESTO- $n$ のモノ マーに相当するポリ(オキシエチレン) モノオレアート 及び代表的な乳化剂である Tween 80/Span 80 〔ポリ (オキシエチレン)ソルビタンモノオレアートレソルビタ ンモノオレアートの混合物了を用いた。またそれぞれの 乳化剂は, 各油を乳化するのに最適な HLB (所要 HLB) のものを用いた。図からわかるように ESTO- $n$ はもっとも低濃度から乳化を女定化できるという特長が ある。前述したように HLB を同じに保ったままでの疎 水部の多鎖化は分子量の増大を意味するから一般にオリ ゴマー型界面活性剤はモノマー型界面活性剂に比べて溶 解エンタルピーが大きく, したがって水への溶解度が小 さい。つまり単分子分散の飽和值, 言い換えれば $\mathrm{cmc}$ が低いために低濃度から乳化剂として有効に作用するの である。例として図-6に ESTO-30, ESTO-60 及び相 当するモノマー型のポリ(オキシエチレン)（5）モノオ

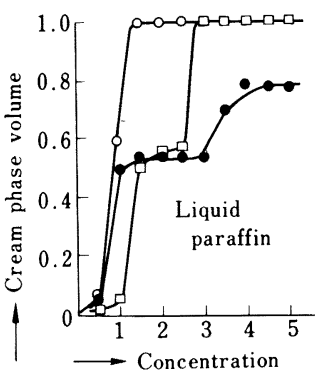

: ESTO-40 $\operatorname{POE}(20)$ sorb

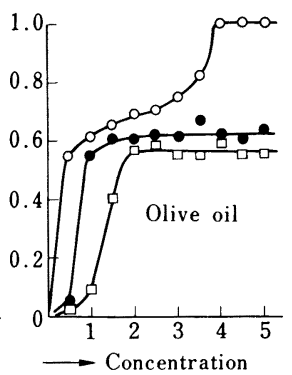

$$
\bullet
$$

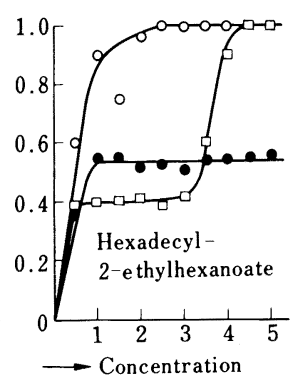

wt. $\%$

図-5 界面活性剂濃度がエマルションの安定性に及ぼす影響 


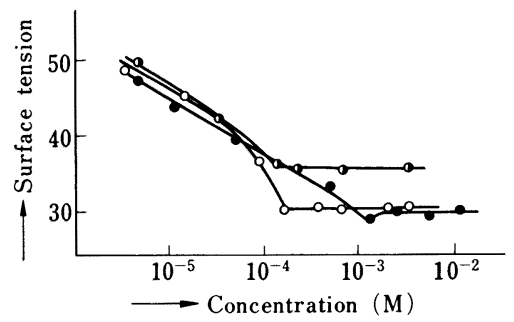

: ESTO-30, $\bullet:$ ESTO-60,

- : $\mathrm{POE}(5)$ mono-ol eate

図-6 各種の界面活性剂水溶液の表面張力一濃度曲線

レアートの表面張力濃度曲線を示す ${ }^{5)}$ 。オリゴマー型の 方が cmcがずっと低いことがわかる。

ところで図-5からも予想されるように，オリゴマー 型界面活性剤はへキサデシル 2 エチルヘキサノアートや オリブ油など比較的極性の高い油に対する乳化力が顕著 に優れている。たとえばオリブ油を乳化するのに EST O-40では 4\%の界面活性剤で安定なエマルションが得 られるのに対し，他のモノマー型界面活性剤では $5 \%$ 以 上の界面活性剤を用いても系を安定化することはできな い。オリゴマー界面活性剤は分子量が大きいため, 界面 膜の強度が高く，このことが極性油であっても良好な乳 化ができる理由と考えられる。図一7にはオリブ油のエ マルションの粒度分布を示したが，このように極性油の 乳化の場合にも大変優れた乳化剂であることが多鎖型界 面活性剂の乳化作用の特長亡言える。

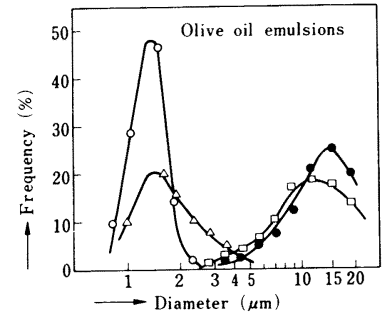

ESTO-30, $\triangle:$ POE $(20)$ sorbitan tri-oleate,

Blends of $\mathrm{POE}(20)$ sorbitan monooleate and sorbitan monooleate,

- : POE (5) monooleate

図-7 各種の界面活性剂で乳化したオリブ油エマル ションの粒度分布

\section{4 親水基としてヒドロキシル基のみ を有する界面活性剤の溶存状態 ${ }^{6)}$}

界面活性剂の基本的性質と言えば，たよえば水溶液の 表面張力や $\mathrm{cmc}$ などが重要な物性值として, しばしば 議論の対象になるが, 水に溶けにくい, あるいは水には ほとんど溶けないような界面活性物質を取り扱う場合,

これらの物性值はあまり意味を持たないことが多い。な ぜなら，水に溶けにくいということは，単分子分散の飽 和値はきわめて小さく，またしばしばミセルを形成する ことなく高次会合体を形成するので $\mathrm{cmc}$ を求めること はできず，さらに通常の条件では均一な水溶液を調製す ることはできないので表面張力の測定もできないからで ある。

ところで一般に天然に存在する界面活性物質は水に溶 けにくいものが多く，たとえばレシチンは自然界に存在 する代表的な界面活性物質で，生体膜の構成成分として も重要な物質であるが，レシチンは二本鎖型界面活性剂 であるため水への溶解度は大变小さく, また水との共存 系においてはミセル溶解することなくマルチラメラ型の 液晶分散系となることが知られている。生体系における 界面活性物質ではこのように水に溶けにくいということ が生体の中で重要な機能を発現するかぎになっていると 考えられている。このような水に溶けにくい界面活性物
R-O- $\mathrm{CH}_{2} \mathrm{CH}-\mathrm{CH}_{2} \quad \mathrm{R}-\mathrm{O}-\mathrm{CH}_{2} \mathrm{CH}-\mathrm{CH}_{2}-\mathrm{O}-\mathrm{CH}_{2} \mathrm{CH}-\mathrm{CH}_{2}$ $\mathrm{OH} \mathrm{OH} \quad \mathrm{OCH}_{3} \quad \mathrm{OH} \mathrm{OH}$ GE DGE-OMe

R-O- $\mathrm{CH}_{2} \mathrm{CH}-\mathrm{CH}_{2}-\mathrm{OCH}_{3}$<smiles>COCC(O)CO</smiles>

IDGE-OMe $\left.\left.\mathrm{R}: \mathrm{CH}_{3}+\mathrm{CH}_{2}\right)_{m} \mathrm{CH}+\mathrm{CH}_{2}\right)_{n}$ $\mathrm{CH}_{3}$ $(m+n=15)$

図－8アルキルグリセリルエーテル誘導体の分子構造
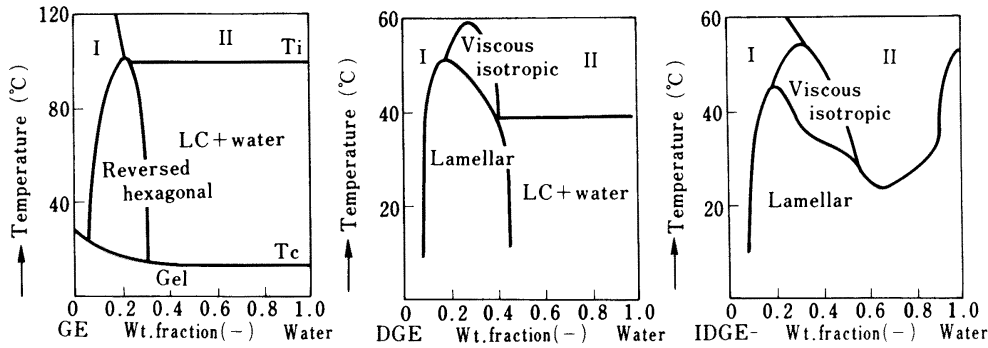

図-9 アルキルグリセリルエーテル誘導体 / 水二成分系相平衡図 
質の基本的な性質を理解する上でも水中溶存状態の解析 は多くの情報を与えてくれる。ここでは水に溶けにくい 界面活性物質として図ー8に示したような一連の長鎖ア ルキルグリセリルエーテルを取り上げた。これらのアル キルグリセリルエーテルはいずれも親水基としてはヒド ロキシル基を持つのみで, 水には溶けにくい物質である。

図ー9にそ机ぞれイソステアリルグリセリルエーテル （以下 GE と略記），イソステアリルジグリセリンエー テル（以下 DGE と略記）及びイソステアリルイソジグ リセリンエーテル（以下 IDGE と略記）之水との二成 分系相平衡図を示した。これら三つの化合物はいずれも 疎水部としてはイソステアリル基を有し, 親水部として は二つのヒドロキシル基を有する界面活性剤であり, 分 子式から計算される HLB 数はほぼ同じであるにもかか わらず，溶存状態は大きく異なっている。

まず GE と IDGE を比較 の形態は前者が逆へキサゴナル型, 後者がラメラ型であ り後者の方が親水性が大きい。また GE の場合, 形成 される液晶が逆へキサゴナル型であるため, 水と液晶と は全く溶け合わず低濃度においては液晶と水が分離共存 している。

一方 DGE と IDGE を比較するとさらに興味深い事 実が見つかる。図-10にФ（Фはここでは水の重量分率 を示す。）を変化させていった時に形成される液晶の面 間隔を小角X線散乱によって求めた結果を示すが,この 図から DGE の場合, $0.10 \leqq \Phi \leqq 0.45$ の範囲では液晶中 の水分量の増加にともなって面間隔が広がっていくが, $0.45 \leqq \Phi て ゙ 一$ 定となり，それ以上の水は $\Phi=0.45$ の時に 形成される液晶の形態, 構造を変化させることなく液晶 相から分離することがわかる。一方, IDGE の場合は $0.15 \leqq \Phi$ の領域でラメラ液晶が形成され, 水分量の増加 にともない面間隔は一方的に増大しており，きわ的て低

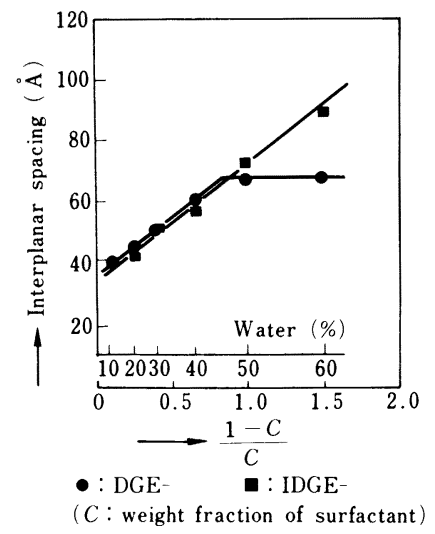

图-10 ジグリセリルエーテル/水系において形成され る液晶の面間隔の变化
濃度までラメラ液晶の一液相が続いている。すなわち DGE ではラメラの層間に取り込まれる水の量に飽和値 $(\Phi=0.45)$ が存在し, それ以上の水は相分離して二液 相になるのに対し, IDGEではきわめて低濃度領域に至 るまで水は相分離することなくラメラ構造の層間に取り 込まれる。つまり, IDGE の低濃度水溶液は層間に多量 の水を含んだ面間隔の非常に大きな液晶となり, あたか も水中に二分子膜が浮かんだような状態となっている。 このため $1 \sim 2 \%$ の水溶液 $(0.98 \leqq \Phi \leqq 0.99)$ では層間距 離は2000 3500 凡も達し, ラメラ層上下の界面で反 射した波長 $4000 \sim 7000 \AA$ の光 (可視光線) が干渉し, 溶液が着色して見える現象が起こる ${ }^{8)}$ 。

このように, DGE よIDGE は異性体であり両者の $\mathrm{H} / \mathrm{L}$ バランスは全く等しいにもかかわらず，溶存状態 は大きく異なり，後者の方が親水性が大きい。これはな ぜであろうか。両者の形成する液晶の構造の微妙な差異 を調べるために, 液晶中に蛍光プローブを埋めこみ，水 分量の変化にともなう親水部, 疎水部の環境变化を調べ

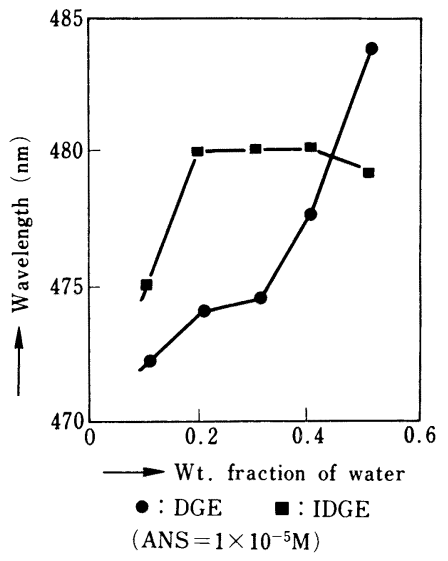

図-11 ラメラ液晶中の ANS の蛍光波長の变化 $\left(25^{\circ} \mathrm{C}\right)$

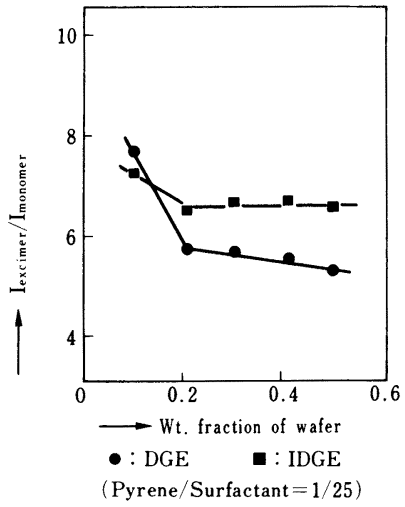

図-12 ラメラ液晶中のピレンのエキシマー濃度の変化 $\left(25^{\circ} \mathrm{C}\right)$ 
た。図ー11はANSを蛍光プローブに使用した時の $380 \mathrm{~nm}$ の励起光に対する蛍光の極大波長の変化を示し ている。DGE の場合, 液晶中の水分量の増加にともな い極大波長が長波長にシフトし，親水部近傍の極性が高 くなっていくことが示されるが, IDGE の場合には親水 部近傍の極性は液晶中の水分量の変化に対して一定であ る。一方，図-12 はピレンのエキシマー発光を利用して 疎水部の環境を調べた結果である。光励起されたピレン のエキシマー形成は一般にピレン分子の置かれている環 境のミク口的領域の固さに依存するが，液晶のような会 合体中ではその構造が密になると励起したピレン分子の 配向が妨げられるため, エキシマー濃度が低下する。 DEG では水分量の増加により徐々にエキシマーの形成 が抑制され，疎水部の固さが増していくが, IDGEでは ほぼ一定であった。これらの結果から, 両者の液晶の構 造変化を模式的に示すと図一13のようになる。

$\mathrm{DGE} /$ 水系では界面活性剂の親水部側と疎水部側の湾 曲傾向が異なるため, ラメラ液晶中の水分量が増すにし たがって, 親水部分が広く露出して ANS の置かれた環 境の極性が高まり, 逆に疎水部は密になって, エキシ マ一の形成が抑制される。これに対し IDGE では液晶 中における界面活性剂の親水部之疎水部の環境は，水分 量の增加によって変化せず，これは親水部側と疎水部側 の湾曲傾向が釣り合っていて，液晶中の水分量が増加し ても平板状のラメラ構造を保持したまま層間に水が入り 込んでいくためと考えら机る。

これらの事実は，液晶を形成して初めて水に溶けるよ うな，水に溶けにくい界面活性剤では，ヒドロキシル基 の数といったいわゆる HLBのような見掛けの $\mathrm{H} / \mathrm{L}$ バ ランスよりも, 分子の立体的形状をも含む分子構造が会 合性あるいは水への溶解挙動に大きな影響を及ぼすこと を示している。
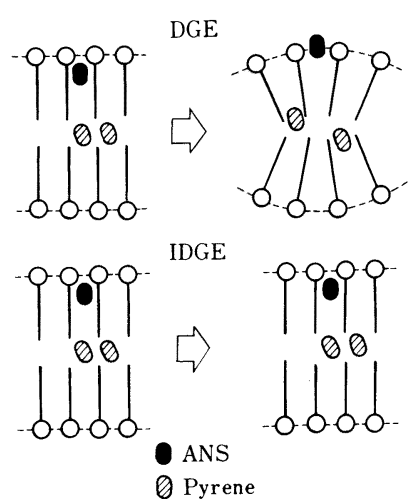

図-13 DGE 及び IDGE の液晶の形態変化のモデル図

\section{5 親水基としてヒドロキシル基のみを 有する界面活性剂の乳化特性 ${ }^{9}$}

前項で述べたように親水基としてヒドロキシル基のみ を有する界面活性剤は水に溶けにくい界面活性剂であ り, 水に溶ける場合は液晶のような高次会合体を形成し て初めて水に溶ける。このような界面活性剂を乳化剂と して利用した場合，よ゙のような特性を示すのだろうか。 ここでは親水基としてヒドロキシル基のみを有する界面 活性剤として $\alpha$-モノイソステアリルグリセリルエーテ ル $(\mathrm{GE})$ を取り上げ，その乳化剤としての特性を溶存 状態の変化という立場から考察してみた。

図一14 は GE を含む各種の界面活性剂を系に対して $5 \%$ 用い，水之油の比率を変えて乳化を行った時に得ら れるエマルションの定性の測定結果を示している。用 いた界面活性剤はすべて HLB 数 5 以下の親油性の界面 活性剂であるため, 得られるエマルションの乳化型はす べて W/O 型であるが, 特徵的なことは GEによる乳化
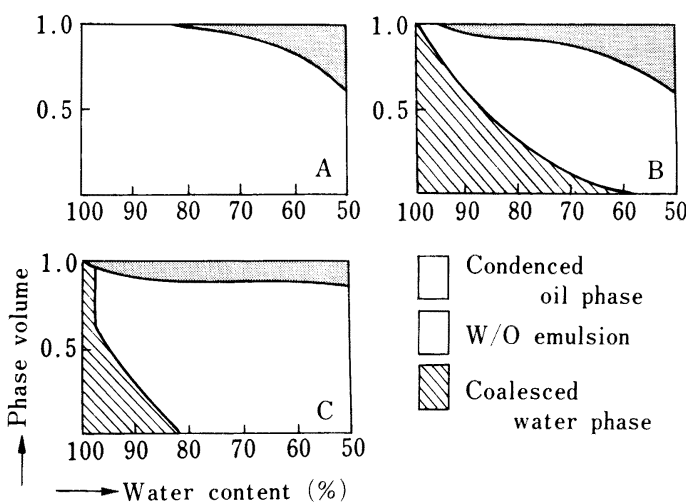

A: GE, B : Glycerol monostearate

C : Sorbitan monooleate

図-14 各種の界面活性剂で乳化した $\mathrm{W} / \mathrm{O}$ エマルショ ンの安定性 $\left(25^{\circ} \mathrm{C}, 7\right.$ 日後の相分率 $)$

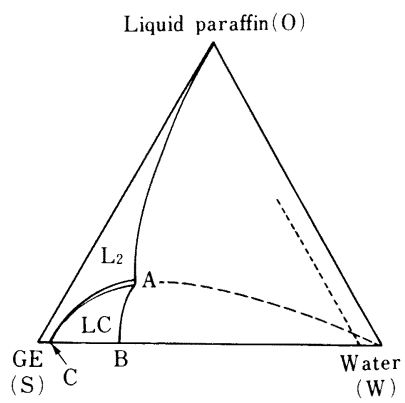

図-15 $\mathrm{GE} /$ 水 / 流動パラフィン三成分系相平衡図 $\left(25^{\circ} \mathrm{C}\right)$ 
系では, 水分量がかなり高くても安定な W/O エマル ションが得られることである。W/Oエマルションの場 合, 水分量の增加は連続相容積の隇少を意味するから, 通常は合一に対する安定性が悪くなる。事実, 比較とし て用いた他の界面活性剂では水分量の多い組成では合一 水相が認められ, 安定性が著しく悪くなっている。しか し GE の場合にはむしろ水分量が多い方が, かえって 安定性が高く, 水分量 $95 \%$ 以上でも合一も凝集も認め られない安定な W/Oエマルションとなる。なせ $\mathrm{GE} に$ はこのような特徴的な乳化作用があらわれるのだろう か。

この理由を理解するために, 水/油/界面活性剂三成 分系における溶存状態を検討してみた。図一15に GE/ 水/油三成分系の相平衡図を示した。図中 $\mathrm{L}_{2}$ で示した 領域は界面活性剂の油溶液, つまり W/O 型の可溶化領 域であり, LC で示した領域は逆へキサゴナル型の液晶 相である。液晶相を一液相と考えるならば曲線 $\mathrm{OAB}$ は $\mathrm{GE}$ 存在下の油/水相互溶解度曲線と見なすことができ る。一方, 前項で述べたように, $\mathrm{GE}$ 之水之は互いに溶 け合わないので, それぞれの相に対し溶解度が存在する と考えられる。したがって油存在下の GE/水相互溶解 度曲線 $\mathrm{CAW}$ を仮想的に考元ることができる。もちろ ん油之水は互いに混じり合わないので, 曲線 CAW は 実測されないが, 油の代わりにエタノールを用いれば明 らかに $\mathrm{GE} /$ 水相互溶解度曲線が確認される。(図-16)

ところで図ー14 に示したエマルションの組成領域は図 -15において点線で示した部分に相当するが, 安定性の 高いエマルションが得ら机る組成領域は二つの相互溶解 度曲線, すなわち $\mathrm{GE}$ 存在下の油/水相互溶解度曲線 之油存在下の $\mathrm{GE} /$ 水相互溶解度曲線のそれぞれ内側に ある領域 ABW 内にあることがわかる。ここで図-15 における四つの領域の溶存状態について考えてみると, 領域 OACS は GE/水相互溶解度曲線 CAW の外側にあ るので一液相と見なせるが, 一方領域 $\mathrm{ABC}$ の液晶が油 の存在によって一液相となった領域, 言い換えると液晶 が過剩の油に“溶解”した領域 (LC in Oil) とも考え られる。領域 $\mathrm{OAW}$ はやはり $\mathrm{GE} /$ 水相互溶解度曲線

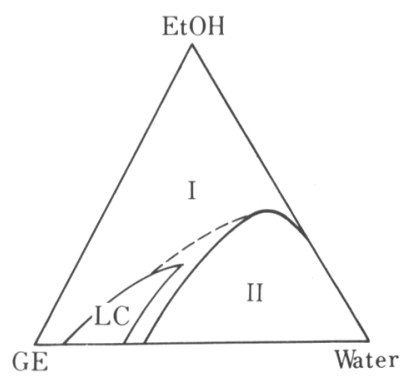

図-16 GE/ 水/エ夕ノール三成分系相平衡図 $\left(25^{\circ} \mathrm{C}\right)$

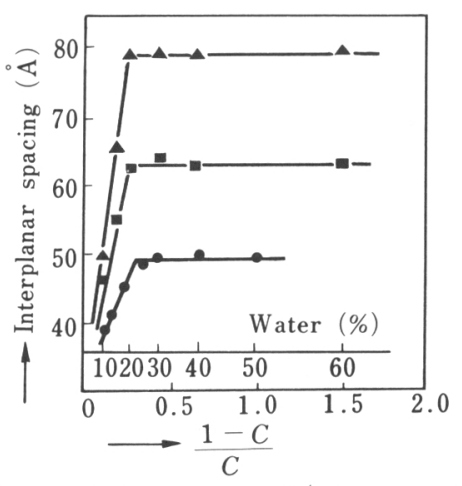

$C:$ Weight fraction of $\mathrm{GE} /$ Liquid paraffin mixture

- : $\mathrm{GE} / \mathrm{oil}=10 / 0 \quad \Delta: \mathrm{GE} / \mathrm{oil}=9 / 1$

- $\mathrm{GE} / \mathrm{oil}=8 / 2$

図-17 GE/水/流動パラフィン三成分系液晶の面間 隔の変化

$\mathrm{CAW}$ の外側であるので油相であるが, 油/水相互溶解 度曲線 $\mathrm{OAB}$ の内側であるので油相と水相の二液相とも 見なせるので, 結局 (LC in Oil) $+\mathrm{W}$ と考えられる。領 域 $\mathrm{ABW}$ は油 / 水相互溶解度曲線 $\mathrm{OAB}$ の内側であるの で油相と水相の二液相であるが, 領域 $\mathrm{ABC}$ が液晶相で あるので $\mathrm{LC}+\mathrm{W}$ となる。つまり領域 $\mathrm{ABW}$ は液晶相と 水相から成り, 油はすべて液晶中に存在することにな る。これが $\mathrm{W} / \mathrm{O}$ エマルションにおいて油相の合一分離 が起こらない理由であると考えられる。

領域 $\mathrm{ABW}$ が液晶相上水相の二相のみから成るこ上 を確認するため, X線小角散乱を測定した。結果を図一17 に示す。GE と油の比較が 10/0 8/2 の範囲におい て, 水分が $23 \%$ までは水分量の増加にともなって面間 隔が広がり、この範囲では水は徐々に液晶の内部に取り 込ま机ていくことがわかる。しかし水分量が $23 \%$ を超 えると面間隔は一定となり, 液晶と水が相分離する。こ れは, それ以上の水は液晶の形態を变化させることなく

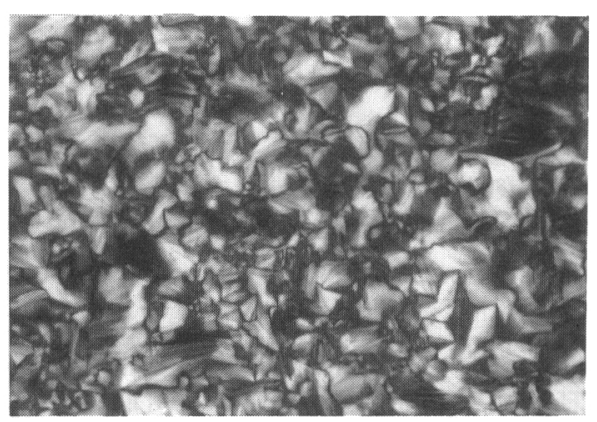

図-18 GE/水 / 流動パラフィン三成分系液晶の偏光 顕微鏡下の組織像 
系外へ分離することを意味している。つまり, 領域 $\mathrm{ABW}$ 内においても，水分量 $23 \%$ の時に形成される液 晶と同じ組成の液晶が存在することになる。ところで LC 相内に存在する液晶の形態は図-18 の偏光顕微鏡像 に示すように逆へキサゴナル型である。逆へキサゴナル 型液晶はラメラ型液晶に比べ粘性が高く, このためにわ ずかの液晶相で大量の水を含むエマルションを安定化で きるのであろう。

以上の結果より, GE の形成する高水分 $\mathrm{W} / \mathrm{O}$ エマル ションは通常のエマルションのような水相と油相とが平 衡にある二液相ではなく, 液晶が界面膜あるいは連続相 となったエマルションであることが理解され，このため に界面膜の機械的強じん（勒）性が高く, 高水分量で あっても合一が起こらない安定なエマルションとなると 結論される。

このように水に溶けにくい界面活性剤では乳化剂とし ての性質も興味深いものがある。

\section{6 おわりに}

本稿では界面活性剤の溶存状態の解析が, 乳化剂とし ての特性をはじめ, 多くの基本的性質を理解する上で,
大変有用な手段であることを，2，3 の例をもって示した つもりである。しかし例に取り上げた界面活性剤は必ず しも一般的な構造のものではなく、ここで述べた結論が どこまで一般化できるか, まだ明らかでないところも多 い。今後さらに多くの例を積み重ね, 体系的な理解を深 めたいと考えている。おわりに当たって本稿が, 界面活 性剤を利用しようとする立場の方に少しでも参考になれ ば幸いである。

(昭和 63 年 7. 月 19 日受理)

\section{文献}

1）塘 久夫，日化，1981，1691

2) T. Kuwamura, H. Takahashi, T. Ilatori, J. Am. Oil Chem. Soc., 48, 29 (1971)

3) K. Kenjo, Bull. Chem. Soc. Jpn., 39, 685 (1966)

4) H. Tsutsumi, H. Nakayama, K. Shinoda, J. Am. Oil Chem. Soc., 55, 363 (1978)

5）塘 久夫, 林 静男, 香粧誌, 2, 26 (1978)

6) 鈴木裕二, 塘 久夫, 油化学: 36, 947 (1987)

7) 塘 久夫, 石田篤郎, 油化学, 33, 270 (1981)

8）鈴木裕二, 塘 久夫, 油化学, 33, 786 (1981)

9）鈴木裕二，塘 久夫, 油化学, 36, 947 (1987) 